\title{
Current Problems and Challenges in International Space Law: Legal Aspects
}

\author{
Inesa Kostenko \\ Ph.D. in Law, Associate Professor, Yaroslav Mudryi National Law University \\ (Kharkiv, Ukraine) \\ E-mail: inessakostenko2014@gmail.com \\ https://orcid.org/0000-0002-8784-5422
}

Kostenko, Inesa (2020) Current Problems and Challenges in International Space Law: Legal Aspects. Advanced Space Law, Volume 5, 48-57. https://doi.org/10.29202/asl/2020/5/5

The article is devoted to the study and research of contemporary legal issues in the field of international space law. Today we are witnessing the rapid and unstoppable development of the space industry. Such cooperation requires an appropriate legal framework. In this article, we will review the leading normative legal acts regulating relations in outer space today and analyze current development trends and problems.

Space law is a relatively new branch of international public law, involving a combination of customs and treaties. The legislative framework of the space industry is expanding accordingly to the subject that is regulated. One of the main issues that are investigated in this article is the search for a balance between free access of humanity to the space and the opportunity to establish ownership of certain study objects in outer space. The ability to develop the right of ownership of private enterprises, companies, research centers is extremely important for the economic development of the space industry.

This article aims to provide a holistic understanding of current trends and challenges in space law with particular emphasis on such issues as space tourism, the "new space" and climate change. The article will examine the founding treaties of space law, the legal framework, and scientific literature concerning space law. The leading goal of this article is to highlight new trends and prospects of space research, the exploration of new perspectives, which are distributed today in the field of outer space, and search of ways of its solution within the framework of legislative regulation.

Keywords: United Nations Office for Outer Space Affairs, European Space Agency, European Space Research Organization, space treaties, space, tourism, privatization, commercialization, new space, climate change, debris.

Received: March 20, 2020; accepted: April 18, 2020

(C) Kostenko, Inesa, 2020 


\section{Introduction}

The development of human civilization is a leading factor in expanding the boundaries of such science as international law. The law of the sea emerged because of the conquest of the ocean by humans. The law for the regulation of airspace relations resulted from the use of aircraft and the conquest of the sky. In such a way, next branch of international law - the law of airspace — was created. Outer space becomes the next, precisely as a result of the subjugation of space by humans. So, the issue of regulating relationships in this branch and setting legal rules becomes acute.

Currently, controversial questions concerning the legal status of airspace continue to compete with each other. The peak of this problem we can observe at the beginning of the $20^{\text {th }}$ century when people finally conquered the air with the help of new technology - aircraft. However, humanity does not stand still, and the next step was the conquest of outer space. At present, there are certain kinds of territories recognized in international law as falling outside the construct of state sovereignty. The following territories include high seas, international seabed its soil and subsoil under the high seas, Antarctica and outer space. To use the designated areas for peaceful purposes and the benefit of humanity as a whole, the international community of sovereign states has created the standard of a "common heritage of mankind."

The concept of "common heritage of mankind" consists of five main elements: the absence of a right of appropriation; the duty to exploit the resources in the interest of mankind in such a way as to benefit all, including developing countries; the obligation to explore and exploit for peaceful purposes only; the duty to pay due regard to scientific research; the duty duly to protect the environment. Such a concept of the "common heritage of mankind" was extended to the new frontier human managed to reach — the cosmos (Richards, 2013).

Most of the leading scientists consider the date of the beginning of legal relations concerning space exploration as 1957, which was well-known as the year when the first artificial satellite had been launched into Earth. At that time, there were no comments or objections from other states concerning this event. There was no state which asked the question of sovereignty. The lack of protest from the members of the international community led to the freedom of scientific exploration in space. This rule helps to expand the area of space research (Tronchetti, 2013).

To sum up, all the above-mentioned events have led to the formation of international rules and principles in the field of outer space, which now makes up the system of legal acts. Current space law extends to the issues such as satellite telecommunications networks, the geostationary orbit, satellite distribution, remote sensing, the operation of the civilian international space station and space debris guidance.

\section{Overview of the five U.N. space treaties}

Concerning international law treaties, we should mention that the United Nations General Assembly has adopted several resolutions regarding the matter. It is advisable to outline the most important of them.

The Resolution 1472 (XIV) of 1959 establishes the Committee on the Peaceful Uses of Outer Space (COPUOS). Considering that the overriding goal of space exploration and exploitation should be only for the betterment of mankind and to the benefit of States regardless of their stage of economic or scientific development, the Resolution commends to States for their guidance in the exploration and use of outer space the following principles: (a) International law, including the Chapter of the United Nations, applies to outer space and celestial bodies; 
(b) Outer space and celestial bodies are free for exploration, and use by all States in conformity with international law and are not subject to national appropriation; c) Invites the Committee on the Peaceful Uses of Outer Space to study and report on the legal problems which may arise from the exploration and use of outer space (RES 1472 (XIV), 1959).

The Resolution 1721 (XVI) of 1961 International cooperation in the peaceful uses of outer space. The main task of the Resolution was to strengthen the idea of peaceful use of outer space, as well as to introduce a voluntary system for the registration of space objects in the international registry. It also represented the effort of UNCOPUOS to set aside any statements that outer space could eventually constitute a form of res nullius, therefore subjected to sovereignty claims. Also, it should be noted that the provisions outlined in the Resolution form the leading opinion on the principle non-appropriation of outer space was already effectively consolidated in International Law by that time (Resolution 1721 (XVI), 1961).

The Declaration of Legal Principles Governing the Activities of States in the Exploration and Uses of Outer Space (General Assembly resolution 1962 (XVIII) of 13 December 1963). Following the provisions of the statutory instrument, States shall be guided by relevant principles during the exploring and using outer space. It is advisable to mention the most important of them:

a) the research and use of outer space shall be for the benefit of all mankind;

b) outer space and celestial bodies are free for study and use by all states based on equality;

c) outer space and celestial luminaries are not subject to sovereignty by appropriation;

d) the activities of States in the exploration and use of outer space shall be carried out under international law, including the Charter of the United Nations, in the interest of maintaining international peace;

e) States should bear responsibility for national space activities carried out by government agencies or non-governmental organizations. The activities of non-governmental organizations in space require an appropriate authorization, supervision, and control;

f) an important principle in the exploration and use of outer space is also mutual assistance and cooperation;

g) the object launched into space must be subordinate to the country to which it belongs. It should be noted that the state should be responsible for the objects and property of objects placed in space, and their parts are not affected by their passage through space or return them to the Earth (Declaration, 1962).

The Principles Governing the Use by States of Artificial Earth Satellites for International Direct Television Broadcasting (Resolution 37/92, 1983). According to the provisions of this regulation, each state has an equal right to carry out activities in the field of international direct television broadcasting by satellite and to allow such activities to persons and institutions under its jurisdiction. Also, access to technology in this field should be accessible to all states without discrimination. It should be noted that the Charter of the United Nations, the Treaty on Principles Governing the Activities of States in the Exploration and Use of Outer Space, including the Moon and Other Celestial Bodies are the leading normative legal acts, their provisions are at the core of activities in the field of international direct television broadcasting by satellite. Concerning the state responsibility, it is reasonable to highlight that in the case where international direct television broadcasting by satellite is provided by an international 
intergovernmental organization, the responsibility should rest with both that organization and the States participating in it (Resolution 37/92, 1983).

The Principles Relating to Remote Sensing of the Earth from Outer Space. Following these provisions, fifteen principles should be realized. It is advisable to mention the most important of them. Remote sensing activities can only be done for the benefit or in the interests of all countries, and it is not dependent on the economic or social development of the countries. The regulatory legal act in this activity is the Treaty on Principles governing the activities of States in the Exploration and Use of Outer Space, including the Moon and other Celestial Bodies, according to which exploration and use of outer space establish the principle of freedom of exploration and use of outer space based on equality. To maximize the impact of remote sensing activities, States are encouraged to implement through the agreements the operation of data collection and storage stations, processing, and interpretation facilities. As a result of the creation of primary and processed data relating to the territory under its jurisdiction, the State concerned will have access to it on a non-discriminatory basis and at a reasonable cost. The Earth remote sensing State shall, upon request, consult with the state whose territory is being sensed to provide opportunities for participation and enhance the mutual benefits arising from there. This is to facilitate and enhance international cooperation. In compliance with Article VI of the Treaty on Principles, States that operate remote sensing satellites should bear global responsibility for their activities, including the Moon and Other Celestial Bodies. Such actions shall be conducted following these principles and rules of international law, whether undertaken by governmental or non-governmental organizations or through international organizations to which such States are parties. In the event of a dispute arising out of the application of these principles, such dispute shall be settled amicably (Resolution 41/65, 1986).

By The Principles Relevant to the Use of Nuclear Power Sources in Outer Space (RES $47 / 68,1992$ ) states launching space facilities with nuclear energy sources should protect people, the general public, and the biosphere from radiological hazards. The use of space objects with nuclear energy sources should provide a high degree of security. International Commission on Radiological Protection notes that during regular operation of space facilities with nuclear energy sources on board, should be investigated and controlled, including re-entry from high enough orbits. The purpose of this is to protect the public. Besides, it should be noted that the design and construction of a nuclear energy source system must take into account relevant international radiological protection rules. Following Principle 5 Notification of re-entry, any state launching a space object with nuclear power sources on board shall in a timely fashion inform States concerned in the event this space object is malfunctioning with a risk of re-entry of radioactive materials to the Earth. The information shall be per the following format: (a) System parameters: (i) Name of launching State or States, including the address of the authority which may be contacted for additional information or assistance in case of an accident; (ii) International designation; (iii) Date and territory or location of launch; (iv) Information required for best prediction of orbit lifetime, trajectory and impact region; (v) General function of spacecraft; (b) Information on the radiological risk of nuclear power source(s): (i) Type of nuclear power source: radioisotopic/ reactor; (ii) The probable physical form, amount and general radiological characteristics of the fuel and contaminated or activated components likely to reach the ground. The term "fuel" refers to the nuclear material used as the source of heat or power (RES 47/68, 1992).

And the last declaration of the peculiarities of which is expedient to outline is the Declaration on International Cooperation in the Exploration and Use of Outer Space for the Benefit and the Interest of All States, Taking into Particular Account the Needs of Developing 
Countries (resolution 51/122 of 13 December 1996). By the provisions specified in this legal action and considering the need of States for technical assistance and the rational and efficient allocation of financial and technical resources, international cooperation should focus on the following objectives: (a) Promoting the development of space science and technology and its applications; (b) Fostering the development of relevant and appropriate space capabilities in interesting States; (c) Facilitating the exchange of expertise and technology among States on a mutually acceptable basis. It is also important that national and international agencies, research institutions, development assistance organizations have a scientific obligation to carry out research, study, and use of space programs and the potential of international cooperation to achieve good development. For this purpose, the Committee on the Peaceful Uses of Outer Space should strengthen its role in the area of international cooperation in the field of Outer Space Use international cooperation following their outer space capabilities and their involvement in space exploration and utilization (Resolution 51/122, 1996).

Subsequently, as a result of the U.N.'s endless efforts at regulating the conduct of space exploration nations, new international treaties in the field of space were introduced and drafted. It should also be noted that the Committee on the Peaceful Uses of Outer Space is a forum for the development of international space law. An essential result of the Committee's work is the conclusion of five international treaties and sets of space activity principles. Such treaties were implemented under the auspices of UNCOPOOS. It is advisable to outline the most important of them: The 1967 Treaty on Principles Governing the Activities of States in the Exploration and Use of Outer Space, including the Moon and Other Celestial Bodies (known as "Outer Space Treaty"); The 1968 Agreement on the Rescue of Astronauts, the Return of Astronauts and the Return of Objects Launched into Outer Space (the "Rescue Agreement"); The 1972 Convention on International Liability for Damage Caused by Space Objects (the "Liability Convention"); The 1975 Convention on Registration of Objects Launched into Outer Space (the "Registration Convention"); The 1979 Agreement Governing the Activities of States on the Moon and Other Celestial Bodies (the "Moon Treaty"). What are the main goals of these treaties? First of all, these treaties regulate the issue of the prohibition of space allocation by any country, control the issue of arms, establish rules on freedom of exploration, specify the legal framework of liability for damage caused by space objects, prescribe rules for the salvation of spacecraft and astronauts in case of danger, as well as the use of natural resources. Analyzing these treaties, we can observe that outer space, space-based activities, and any benefits that can be gained from space must be dedicated to enhancing the well-being of all countries and humanity.

\section{Overview of the United Nations Office for Outer Space Affairs (UNOOSA)}

UNOOSA is the United Nations office responsible for promoting international cooperation in the peaceful uses of outer space. UNOOSA located at the United Nations Office at Vienna, Austria. Nowadays, UNOOSA represents the main organization for space affairs within the U.N., which implements the decisions of the G.A. and the UN COPUOS ${ }^{1}$, and is the primary

${ }^{1}$ The Committee on the Peaceful Uses of Outer Space (COPUOS) was set up by the General Assembly in 1959 to govern the exploration and use of space for the benefit of all humanity: for peace, security and development. The Committee was tasked with reviewing international cooperation in peaceful uses of outer space, studying space-related activities that could be undertaken by the United Nations, encouraging space research programmes, and studying legal problems arising from the exploration of outer space. 
international forum for the development of laws and principles governing outer space. Its field of activity is to support intergovernmental discussions and the Committee and its Scientific and Technical Subcommittee and Legal Subcommittee. Moreover, it assists developing countries in using space technology for development and also follows all scientific and technical developments relating to outer space affairs. It maintains the Register of Space Objects on behalf of the Secretary-General and also collects other relevant data and documentation (Resolution 47/68, 1992). UNOOSA's main objectives are to promote international cooperation in peaceful uses and space exploration. It is also important to highlight that the use of space science and technology contributes to economic and social development, the establishment and implementation of a legal framework in the field of space relations regulation, and the implementation of programs aimed at the development and integration of space capabilities in international development programs.

It is interesting to note that the U.N. Office for Outer Space was created only as a small expert unit within the United Nations Secretariat to serve the Special Committee on Peaceful Uses of Outer Space, set up by the General Assembly in its resolution 1348 (XIII) of 13 December 1958. However, the further history of U.N. development is that this department was reassigned to the Department of Political and Security Services in 1962. Later, in 1968, the department was transformed into the space unit of the Department of Political Affairs. In 1993 the Office was transferred to the U.N. Office in Vienna and set itself new responsibilities, such as responsibility for essential secretariat services to the Legal Subcommittee, which had previously been provided by the Office of Legal Affairs in New York.

The leading functions of UNOOSA include the implementation of the tasks of a single General Assembly Committee that deals exclusively with international cooperation for peaceful uses of outer space: the U.N. Committee on Peaceful Uses of Outer Space (COPUOS). Also, UNOOSA conducts international seminars, training courses, and pilot projects on topics including remote sensing, satellite navigation, and satellite meteorology and prepares and disseminates reports, research, and publications in various fields of space science and technology and international law. Such activities are usually supported by the United Nations Space Program.

It should be noted that such UNOOSA's activity as promoting international cooperation in peaceful uses and space exploration is a leading factor in the sustainable economic development of countries. UNOOSA helps United Nations Member States to create the legal and regulatory framework for space management so that countries with low economic development are now able to develop through collaboration and use of space scientific technologies (Bohinc, 2013).

\section{Current problems in international space law}

In practice, today, we can observe that some new businesses break the rules, ignore and contradict existing international space agreements. Today, the Space Law is a combination of rules and customs aimed at ensuring the free, unhindered, and non-discriminatory access of mankind to space. As already mentioned, the leading treaties in the field of the application of space law today are the "Treaty on the Principles Governing the Activities of States in the Exploration and Use of Outer Space (OST), Including the Moon and Other Celestial Bodies" of 1967; the 1968 "Rescue Agreement," the 1972 "Liability Convention," the 1975 "Registration Convention" and the 1979 "Moon Agreement." Today those founding treaties of Space Law find many issues unaddressed. It should also be noted that today most of the leading scientists believe 
that much attention is needed to the development of space tourism, "New Space," space debris, and climate change. Therefore, given the fact that the space environment is changing today and quite actively, there is an increase in the number of private companies whose activities are related to space - there is a need to improve legislation, international treaties on space and land-based activities. It should be understood that the old rules and customs need their renewal today.

For example, asteroids are known to be rich in valuable resources like iridium, platinum, and palladium, which are rare on Earth. Because of the high value of these materials, mining expeditions are expected to be a frequent phenomenon. The critical question then is, "Who will own those mined resources?" When national councils and private operators are predicated on an ownership basis, this causes concern. Accordingly, countries should look at detailed national legislation for outer space activities (Roles, 2020).

Regarding the leading and defining legislative acts in the field of space relations regulation, the Law on Space Regulation should be mentioned. For example, the Space Settlement Institute based in New York has put forward a proposal to introduce a legislative act which is possible to regulate property rights relations. This law provides legal support for land ownership "for any individual who has established a settlement on the Moon, Mars, or a permanent asteroid, with regular traffic between the settlement and the Earth open to any paying passenger." Therefore, according to the provisions of this law, any private company can create and settle settlements on Mars without the government of its state. As a result, private space settlements should not be subject to the sovereign jurisdiction of any terrestrial nation. This will help to remedy the situation in such a way that private property rights will be secured and the issue of national allocations resolved.

Nowadays, not only organizations whose main preoccupation is outer space discuss the possibilities which might arise within this field in the future, e.g., the Competitive Enterprise Institute (hereafter CEI), an NGO organization the main aim of which is entrepreneurship and free-market initiatives. CEI in April 2012 published a paper "Homesteading the Final Frontier - A Practical Proposal for Securing Property Rights in Space” (Simberg, 2012). This paper presented a practical proposal to introduce a new regime. The author argues that space ownership is not just a need for space and development. Recognition by governments and property of space would create a powerful financial incentive to open the space border. According to this understanding, competition in the free market can help reduce the high costs of space-related space activities.

Besides, the proposal elaborates that the 1967 Outer Space Treaty implicitly prohibits private property in outer space, but on the other hand, there are different conceivable interpretations. For example, one of them only forbids declarations of national sovereignty, not only from individuals. In this sense, importance is the ability to maintain freedom, openness, and developing the economy through competition and by reducing political interest in space issues (Gorove, 1969). According to article 2 of the OST, ownership of celestial bodies cannot be invoked. However, this position limits researchers to any type of ownership of their subject matter. Article 2 of the OST creates some contradictions in the contract for the prohibition of property rights for individuals and businesses. Many private companies and individuals, whose home countries are not signatories of the Moon Treaty, use this deficiency to assert their belief that the concept of res nullius remains valid for private individuals and business entities. However, even if one country would decide to use this interpretation, another problem would arise, and that is protecting the claim from others, which could lead to major political repercussions (Brittingham, 2010). 
Therefore, the first changes in the current legislation will become inevitable when the first settlements on the Moon appear and the missions of which will be exploring the Moon for the benefit and in the interest of all countries (i.e., according to the OST stipulation).

The law which we should also mention is the Space and Settlement Development Act of 2019. This law is a refinement and is based on Congressman George Brown's original Space Law. The work on revising the law in the current version was done by Dana Rohrabacher. The principal purpose of the law to outline is to add enabling space development and settlement to NASA's charter, to the Office of Commercial Space Transportation's charter, and the Office of Space Commerce charter. The act is included in the Alliance for Space Development's ${ }^{2}$ MarchStorm event, and its passage is the cornerstone of the Space Settlement Campaign, a joint project between the National Space Society and the Waypaver Foundation (Dunstan, 2012).

Following this law, the development of space will create new jobs, catalyze new industries, accelerate innovation and new technologies, and enable the United States to tap vast new resources that will generate new wealth, enhance national security (The Space, 2019). Consistent with the national security interests of the United States, the Office of Science, Technology, and Policy shall, in close cooperation with the National Aeronautics and Space Administration, the Department of Transportation, the Office of Space Commerce, other appropriate agencies, the private sector, academia, and the international community, obtain, produce, and provide information relating to all issues important for the development of a thriving space economy and the development and establishment of human space settlements (The Space, 2019).

\section{Commercial space tourism}

Today, as we examine this issue, we realize that many risks are hidden. These include technological risks, liability, and security issues. At present, the topic of rescue and security is not new, because there are treaties and agreements concerning it. For example, Article V of the 1967 Rescue (RES 2345 (XXII), 1967) addresses near exclusively "the return of astronauts and space objects," the "assistance to astronauts" and the "obligation to inform other states and the U.N. Secretary-General of any phenomena liable to constitute a danger to the life or health of astronauts" (H.R.4752, 2016). Interestingly, the cosmonauts should assist other astronauts, but there is no such obligation on the partner countries. At present, the law on the rescue of space flight participants is insufficient, since in recent years the rules have been prescribed only for astronauts. Existing general humanitarian obligations to assist people in distress would prevail. Regardless, it would be beneficial for the international community to clarify the status of "space-flight participants" and the applicability of the Rescue Agreement, which would then lead to the clarification of provisions and the subsequent elimination of conflicting laws and practices (Forganni, 2017). Among the most significant challenges facing the international community in the coming years are the commercialization of space and the ever-increasing amount of space debris. Other issues, such as ownership of space objects,

${ }^{2}$ The Alliance for Space Development (ASD) is a group of 15 non-profit member organizations working together toward the goals of space development and settlement. Its members include The National Space Society, The Space Frontier Foundation, The Lifeboat Foundation, The Mars Foundation, The Mars Society, The Moon Society, The Space Development Foundation, The Space Development Steering Committee, Space for Humanity, Space Renaissance USA, the Space Tourism Society, Students for the Exploration and Development of Space (SEDS), Tea Party in Space, and the Waypaver Foundation 
space resources, will become more important with the development of space technology and their various uses.

\section{Conclusion}

Today's space law is a young branch of international law, a new and dynamic sphere of application of international legal norms. This branch needs further development, given the rapid and unrestrained dynamics of space science, the latest space technologies, satellites, the widespread use of mobile communications and the Internet. As a result of careful scientific analysis of trends and problems in outer space, we can predict that the commercialization of the economy will inevitably become imminent shortly. Concerning new activity, it should be noted that the area of asteroid production is quite enjoyable now.

Therefore, the emergence of complex legal issues for international communities, space companies, and legislatures is inevitable. Expected events are that private entrepreneurs and businesses will be active actors and will increase their stake in space operations in collaboration with government agencies. Therefore, the future of space business and international space law must find a balance between adhering to the basic principles of space law and supporting the private economic sector.

It is entirely foreseeable that as the number of people in outer space increases as a result of the expansion of outer space activities, the law governing human activity in this environment becomes more and more relevant. We should also note that it becomes necessary today to harmonize legislation governing legal relationships in outer space because every day, more and more questions appear that require proper and adequate regulation.

\section{[ㅁ] References}

Bohinc, Erazem (2013) International Space Law: legal aspects of exploiting outer space. Nova Gorica. http://www.unaslovenia.org/sites/default/files/file/Bohinc.pdf

Brittingham, Bryon C. (2010) Does the world need new space law? OREGON REVIEW OF INTERNATIONAL LAW. Vol. 12, 31.p. 44. https://www.peacepalacelibrary.nl/ebooks/ files/35550927X.pdf

Declaration of Legal Principles Governing the Activities of States in the Exploration and Use of Outer Space (1962) https://www.unoosa.org/oosa/en/ourwork/spacelaw/principles/ legal-principles.html

Dunstan, James E. (2012) Dunstan to Remark at CEI's Property Rights in Space Event. Techfreedom. https://techfreedom.org/dunstan-to-remark-at-ceis-property-rights-in/

Forganni, Antonella (2017) The potential of space tourism for space popularisation: An opportunity for the E.U. Space Policy? Space Policy. Volume 41, August, Pages 48-52. https://www.sciencedirect.com/science/article/abs/pii/S0265964616300753

Gorove, Stephen (1969) Interpreting Article II of the Outer Space Treaty. Fordham Law Review. Volume 37 Issue 3. https://ir.lawnet.fordham.edu/flr/vol37/iss3/2

H.R.4752 (2016) The Space Development and Settlement Act. https://www.congress.gov/ bill/114th-congress/house-bill/4752

RES 1472 (XIV) (1959) International Co-operation in the Peaceful Uses of Outer Space https://www.unoosa.org/oosa/oosadoc/data/resolutions/1959/general_assembly_14th_ session/res_1472_xiv.html 
Resolution 47/68 (1992) Adopted on by the U.N. General Assembly on 14 December. Principles Relevant to the Use of Nuclear Power Sources In Outer Space; https://fas. org/nuke/space/principles.pdf

Resolution 1721 (XVI) (1961) International cooperation in the peaceful uses of outer space. Official Records of the General Assembly, Sixteenth Session, Annexes, agenda item 21, document A/4987. https://www.unoosa.org/oosa/en/ourwork/spacelaw/treaties/ resolutions/res 16_1721.html

Resolution 37/92 (1983) Principles Governing the Use by States of Artificial Earth Satellites for International Direct Television Broadcasting; https://www.unoosa.org/oosa/en/ ourwork/spacelaw/principles/dbs-principles.html

Resolution 41/65 (1986) The Principles Relating to Remote Sensing of the Earth from Outer Space (Resolution of 3 December 1986). https://www.unoosa.org/oosa/en/ourwork/ spacelaw/principles/remote-sensing-principles.html

RES 47/68 (1992) Principles Relevant to the Use of Nuclear Power Sources in Outer Space. General Assembly 47th session. https://www.unoosa.org/oosa/oosadoc/data/ resolutions/1992/general_assembly_47th_session/res_4768.html

RES 2345 (XXII) (1967) Agreement Agreement on the Rescue of Astronauts, the Return of Astronauts and the Return of Objects Launched into Outer Space. https://www.unoosa. org/oosa/en/ourwork/spacelaw/treaties/introrescueagreement.html

Resolution 51/122 (1996) Declaration on International Cooperation in the Exploration and Use of Outer Space for the Benefit and in the Interest of All States, Taking into Particular Account the Needs of Developing Countries. https://www.unoosa.org/oosa/en/ourwork/ spacelaw/principles/space-benefits-declaration.html

Richards, Anna M (2013) Short Introduction to Space Law. https://www.academia. edu/1883059/Short_Introduction_to_Space_Law

Roles and Responsibilities (2020) United Nations Office for Outer Space Affairs. http://unoosa. org/oosa/en/aboutus/roles-responsibilities.html

Simberg, Rand (2012) Homesteading the Final Frontier. A Practical Proposal for Securing Property Rights in Space Issue Analysis. COMPETITIVE ENTERPRISE INSTITUTE. No. $3 \mathrm{https} / /$ cei.org/sites/default/files/Rand\%20Simberg\%20-\%20Homesteading\%20 the $\% 20$ Final $\% 20$ Frontier.pdf

The Space Development and Settlement Act (2019) http://allianceforspacedevelopment.org/ wp-content/uploads/2019/space-development-and-settlement-act-of-2019.pdf

Tronchetti, Fabio (2013) Fundamentals of Space Law and Policy. 1st ed. New York and London: Springer Briefs in Space Development, pp. 3-5. https://doi.org/10.1007/978$1-4614-7870-6$ 